\title{
Accounting and Auditing of Intellectual Property in Albania.
}

\author{
Phd. Candidate, Marsel Sulanjaku \\ Lecturer at "A.Xhuvani" University, Faculty of Economic \\ Faculty of Economic, Elbasan \\ e-mail: msulanjaku@gmail.com, telephone: 0692034258
}

\section{Doi:10.5901/ajis.2013.v2n9p400}

\begin{abstract}
Intellectual property is a primary source of value added growth and earning power for the business. In the modern business world there is a general shifting from physical assets towards intellectual property assets such as patents, trademarks, industrial designs, trade secrets, copyrights etc. As the importance and value of these assets for the business is increasing the accountants should take them in consideration more seriously. We will briefly list the accounting and auditing methods used in developed countries for the intellectual property together with the gaps and challenges that the adoption of these standards represent for the accountants and managers. The comparison of these standards and methods with the development made in Albania in this field will be in our main focus. The accounting and auditing practices and challenges of intellectual property for the small medium enterprises in Albania will be another important topic related to the dominant role that SMEs has in the Albanian economy. The research aim is to reveal how the Albanian certified accountants and audits are using the IAS and IFRS for the intellectual property and the difficulties they face to adopt and use these standards in their financial reporting. The methodology used in the preparation of this paper will be that of the utilizing the foreign and national literature, and the utilization of the questionnaires and interviews with the certified accountants and audits as well as the finance departments of selected businesses in Albania.
\end{abstract}

Keywords : Intellectual property, IAS, financial reporting, SME, certified accountants

\section{Introduction}

In a knowledge based economy ,where the capital intense industries are shifting towards knowledge based industries , the intellectual property such as patents, trademarks , trade secrets etc. are becoming the primary ,key element toward sustainable earning and competition power towards other companies. The company's competitive advantages lies therefore largely in its capacity to manage these strategic resources .

The management of assets cannot be done if it is not measured or cannot be valued. Intellectual property makes knowledge functional and managerially controllable, in this sense it may be viewed as "knowledge in action" or a right in an abstract object. ${ }^{1}$

The measurement of the intellectual property ,the abstract objects, has become the new challenge of the accountants. The accounting profession itself is aware of the necessity to reflect the intellectual property in the companies' financial statements.

The main difficulties in intellectual property reporting (IP) is determining the value of this abstract object. Since accounting follows the paradigm of recording business items at their price in a commercial transaction, only IP that is licensed or sold can be reflected on the balance sheet. After the recognition phase the IP will be revalued accordingly, to its market value or fair value. Given the inherent multiple challenges in accurately determining the value of IP, coupled with the volatility of the value of some IP, it is no wonder that the accounting profession (and the market) fears that the reporting of a firm's IP may be considered as too subjective and risky. ${ }^{2}$

\footnotetext{
${ }^{1}$ Moerman , L\&Van Der Loan , S (2006) TRIPS and the pharmaceutical industry prescription for profit . Critical perspectives on accounting. 17,1089-11069

${ }^{2}$ Getting a Grip on Accounting and Intellectual Property.By Roya Ghafele, Associate Economic Officer, Intellectual Property and Economic Development Department, WIPO
} 
The IP accounting and audit issues and challenges faced by the accountants are not much different in Albania . This paper aims to deal with (im)possibility of applying the IAS regarding the IP and the challenges that the Albanian accountants face.

\section{Accounting Issues of Intellectual Property}

Before the introduction of IAS 38 , goodwill, was the only word that represented the intangible assets. Goodwill was defined as the price that the buyer is ready to pay in excess of the value of a company's tangible assets. The concept of goodwill is very general, because every higher value above the tangible assets value was classified as goodwill.

IAS 38 revised the goodwill treatment and specified the IP as an intangible asset when it separable, capable of being separated or divided from entity and sold, transferred, licensed or exchanged, either individually or together with a related contract assets or liability.

The intangible asset, according to the IAS 38 shall be recognized if , and only if :

- They can be separately identified

- It is probable that the expected future economic benefits that are attributable to the asset will flow to the entity, and

- The cost of the asset can be measured reliably.

In practice it is difficult to recognize a concrete , specified IP, because the expected future economic benefits may not be linked to only one intangible, but to more than one intangible asset that the company may have , and it is very difficult, most of time impossible to attribute the right excess future economic benefits to each intangible asset separately.

IAS 38, mention the value and recognition of the IP only in an open market transaction, or business combination at its fair value, leaving the internally developed IP unrecognized. According to IAS 38 internally generated intangible assets shall not be recognized as an asset. The expenses made at research state definitely will be recognized as expense when it has occurred, and it can be recognized in the development stage, if and only if certain criteria like :

- The ability to measure reliably the expenditure attributable to the intangible asset during its development

- The technical feasibility of completing the intangible asset so that it will be available for use or sale.

- Control (power to obtain benefits from the asset)

- Future economic benefits (ability to obtain benefits from assets)

IAS 38 treats the potential same IP in different approach when the IP is acquired and by a different approach or it cannot be recognized at all, when it is internally generated .Internal generated IP can be a major relevance to a firm, even if it is not involved directly in a business transaction.

This may lead to serious confusion. Thus, a company which decides to sell or license internally generated IP appears to create profits virtually out of nothing, because the IP that generated these profits did not appear on its balance sheet. To outsiders, this might look like magic, whereas it is nothing but the expression of unfortunately stated information ${ }^{3}$

Examples where the balance sheets of the IP intense companies are distorted because this gab are not few:

Gillette which value mainly relies on its trademark, had a book value of 3 billion USD, but it was bought by 59 billion USD by Procter \& Gamble which makes up for a gap in the market to book value of 56 billion USD that have never reported anywhere. ${ }^{4}$

Coca Cola keeps its trade secret over its syrup since 1891. Paired with successful trademark management the company's trade secret makes up for most of its success since the 19th century and yet still it cannot report its trade secret value in it financial tables because it is an internally generated IP and the revenue streams cannot be directly related to the syrup unique taste.

From this point of view there is a gap in IFRS and are not well equipped to deal with the IP. This approach is not only by the IFRS but also from the US GAAP, FAS 141 and FAS 142.

\footnotetext{
${ }^{3}$ Licensing Executive Society: Transcription notes of the F-16 Committee Meeting: Reporting Intellectual Property, Washington, D.C., May 2, 2002,

${ }^{4}$ Example given by the FASB (Financial Accounting Standards Board) at the United Nations Department of Economic and Social Affairs Conference, July 12-13 2006
} 
For knowledge based SME, the lack of reporting in their financial tables the value of their IP, or the investments that they make to create an IP, can qualify these enterprises as high risky, from the financial institutions and consequently to raise the cost of the funding. At the stock exchange sectors that strongly depend on IP like high technology or pharmaceuticals are considered more risky, because of inadequate capital and market communications about their IP value , since accounting is not tailored to IP, investors are provided with little or inadequate information on a firm's IP assets. As a consequence it is difficult for a potential investor to adequately assess the risks and benefits of investments. The information vacuum on IP distorts widely, commonly used ratios such as the price / earnings ratio, price /sales ratio and market/book value. These ratios are calculated on the basis of the data provided in the balance sheet, and since IP is missing in the financial reports, the ratios do not reflect the real performance of the business ${ }^{5}$

The impairment of the in-definitive useful life of IP is another topic that creates discussion among accounting professionals.

According to the IAS38 the depreciable amount of an intangible asset with a finite useful life shall be allocated on a systematic basis over its useful life. The useful life of the intangible asset has to be determined according to respective documents and contracts, or for the time that the business entity expects future economic benefits to be generated from the intangible assets.

The in-definitive useful life intangible assets shall not be amortized, but the entity is required to test its in-definitive useful life for impairment, according to IAS 36 "Impairment of assets", by comparing its recoverable amount with its carrying amount. In this group of assets are classified assets like software programs, brand names etc. These intangible assets cannot be amortized, but they will periodically be valued for impairment. The existences of intangible assets with in-definitive useful life are considered to be very risky from the entity's management because of the possible unpredicted, drastic fluctuations that their value might have. ${ }^{6}$ The possible off-impairment charges of these assets have direct, negative impact on the entity's income table, resulting to represent a negative performance for the management.

Valuation of the intellectual property is another challenge, yet to be accomplished by IFRS. The methods described by IAS 38 to value the IP are :

- Cost Model: After initial recognition, an intangible asset shall be carried at its cost less any accumulated amortization and any accumulated impairment losses.

- Revaluation Model: After initial recognition an intangible assets shall be carried at a revalued amount, being its fair value at the date of the revaluation less any subsequent accumulated amortization and any subsequent accumulated impairment losses, and for revaluation purposes, fair value shall be measured by reference to an active market

The cost model is not an adequate model as it has no connection to future benefits that an IP can provide to the entity, and does not necessarily reflect the real actual value of the IP. A patent or trademark might have been inexpensive to create, but its present value can have a significant value, that cannot be reflected in the financial statements. Bu using this model the fair value of the IP is not presented in the financial tables and thus not revealing the value of the entity.

The revaluation model is generated to eliminate the disadvantages of the cost model, by giving more updated information regarding the value of the IP by its fair value, measured by reference to an active market. The challenges with the revaluation model of the IP are related to the active market. An active market is a market in which all the following conditions exist:

- The items traded in the market are homogeneous;

- Willing buyers and sellers can normally be found at any time; and

- Prices are available to the public.

The IP assets are from its nature unique in their nature and differ from each other. For example the patents, trade secrets, trademarks etc. are very unique in their nature and it is very difficult to speak for homogeneous assets. ${ }^{7}$

The real prices of the IP assets hardly are available to the public because the difficulty that have the accountants to determine it real value, bringing in our attention here that only the acquired IP in a market transaction is valued, whereas the internally generated IP is not yet recognized by IFRS.

${ }^{5}$ SEC (Securities and Exchange Commission): Strengthening Financial Markets: Do Investors Have The Information They Need? A Report by the SEC Special Task Force.2001 http://www.mba.yale.edu/news_events/sec_exec_sum.htm

${ }^{6}$ Gordon V.SMITH, Russel L.PARR (2011) , Intellectual Property , Valuations , Exploitation and infringement damages pg 50-54

${ }^{7}$ Sullivan P. (Jr.) \& Sullivan P. (Sr.) (2000). Valuing intangibles companies - An intellectual capital approach. Journal of Intellectual Capital Management. 1(4), 328- 340 
The accounting of IP is a huge challenge for the accountants and managers .More efforts should be done to find more accurate model in evaluation of IP property, because as one of the oldest management cliché says "You cannot manage what you cannot measure"8.

\section{Auditing Challenges of the Intellectual Property}

A company cannot be properly managed if the management cannot identify and measure properly the entity's intangible assets, and cannot understand its options to exploit them. The existence of a protected intangible asset in an entity can raise the entity's value, because the entity is more likely to be profitable in the future.

The focus of an IP audit is to identify and record the IP that an economic entity has acquired or developed in-house, and determine the extent of the business' ownership of those assets. The key audit objectives can be summarized as follows: ${ }^{9}$

1- Identify and record existing and hidden IP acquired or developed by the business.

2- Determine the origin and legal ownership of the identified IP.

3- Identify and evaluate the adequacy of

- Strategic integration of IP management within business overall strategy

- Qualitative valuation which describes the benefits that the IP asset brings to the business

The stage one, defines the scope of the audit and focuses upon the identification of IP assets internally developed and acquired, and seeks to uncover key areas of risk or concern from an IP governance perspective.

The stage two , involves a substantive audit for each IP assets separately , concerning following issues:

- What has been developed or acquired

- Who created or developed the IP

- Who owns the IP? (is sole or joint ownership)

- $\quad$ Are any restrictions for the IP use?

- Is this IP protected and is this type of protection adequate?

- Reviewing the legal agreements of IP protection, including licenses, confidentiality agreements, contractors, joint ventures etc.

- What are the costs of protection and to what extend can this IP be commercialized?

The stage three involves the analysis and reporting of the outcomes of stages 1 and 2 , including recommendations concerning the effective management of IP such as the right to use these assets, defects in IP ownership protection, the current and future profitability for the business through proper management, exploitation of commercialization etc.

The audit of a business entity is a legal and accounting challenge for the auditors and for the business entity an extra costs, that not every business entity can effort. In most countries Small and Medium Enterprises, SME, represent $80-90 \%$ of the enterprises worldwide. SMEs are often the driving force behind a large number of innovations and contribute to the growth of the national economy through employment creation, productive investments and value-added exports. ${ }^{10}$

Most of SME's in developing countries, like Albania, SME's do not use or do not get the best out of their use of their IP. This is mostly related either by underestimating the value that IP can have for the entity or by non affording the proper management costs of IP.

\subsection{Challenges of IP accounting and audit in albania}

Albania has a relatively young experience in adoption of the IFRS. To adapt the domestic legislation in line with the needs of development and harmonization with EU directives, The Albanian council of Accountants started the work for adoption and harmonization of the National Accounting Standards.

\footnotetext{
${ }^{8}$ Stewart, T. (2001). The Wealth of Knowledge: Intellectual Capital and the 21st Century. Organization Currency: New York

${ }^{9}$ Sharyn Ch'ang and Marina Yastreboff , Intellectual Property Auditing: A Road to Riches , 2001

10 http://www.wipo.int/sme/en/
} 
The National Accounting standards (NAS) in adoption to IFRS were first introduced and published in September 2006 and they started to be officially used in January 1.st 2008.

NAS are in total harmonization with IFRS and concretely the Intangible assets (IAS 38) is treated in NAS 5 "Tangible and Intangible Assets" and NAS 9 "Business Combination".

Albania is e developing country where its economy is based mostly on SME and given the significant role of SME's in the national economy in terms of their sizeable contribution to GDP, employment generation and export performance the government seek to encourage the creations and development of these businesses.

Government policy consistently sought to encourage innovation among SMEs, to resist the fast-changing market conditions of the intense global market competition.

In Albania the innovations by SME, consist of minor adoptions to existing products and are mainly of informal nature. The main IP generated by these businesses are industrial designs, trademarks, business location, trade secrets and copyright. 11

Although the increasing number of applications to protect an IP, from the SMEs in Albania a very limited number of entities profits from the potential or actual benefits of their IP. Main reasons for these entities not to recognize and manage their IP are as follows:

- Economical Informality : Most of the SME business are focused to minimize taxation by hiding some of their tangible assets too, and try to declare a lower revenue stream. For these category of entities the main goal is to declare the lowest possible assets value and sales revenue to avoid as much as they can the tax obligations. In this way they do not profit from exploiting in long term ,from their tangible and intangible assets to expand their business and to increase their borrowing capacities from banks ${ }^{12}$.

- Limited knowledge: Another category of these entities do not profit from their IP, because they lack the information of the existence of the IP administrative offices where they can protect their IP and the lack of qualified accountants experienced with the IP treatment.

- Lack of business strategy: Many business owners or management are not in knowledge of the benefits that the proper management and reporting of their IP, in their financial tables, in long run ,can affect positively their business.

- Finding the system complex, inefficient and expensive: There are a considerable number of entities that consider the process of registering and holding an IP protected a complex action that takes more time and money than they can afford. ${ }^{13}$

- Lack of experienced and qualified accountants and managers: Generally the SME's lack of qualified administrative personnel that can manage their respective IP, either in the legal or accounting approach.

\section{Analysis of the Survey}

The survey is conducted mainly to the certified accountants and audits, finance departments and management of the entities. Except the interviewed targets, some individuals were contacted via e-mail or telephone. Their responding rate was relatively high due to the efforts made to receive feedback. The interviewed individuals are asked several questions and below we present the summarized results of their opinions.

1- Asked about their experiences regarding the management and accounting of IP, most of them responded that they have theoretical information about the topic but have not practical experiences. Few individuals from the target group responded positively, here mentioning that most of their experience was in management perspective (registration of the IP in the related offices) and few of the interviewed individuals had experience with the accounting and reporting issues of IP.

2- Asked about if the reporting of the IP on the financial statements of the entities will affect positively the entities performance, we observed that most of the interviewed individuals support positively the idea of reporting the IP in the big companies, and are skeptic for the positive effects that the IP reporting for the SMEs.

- The supporters of IP accounting reporting, are supporting the idea that the IP bookkeeping will affect positively in entities revenues, earning power.

\footnotetext{
${ }^{11}$ Buletini informativ i aktivitetit te zyres Shqiptare per te drejtat e autorit , maj 2011

${ }^{12}$ Buletini i pronesise Intelektual, Drejtoria e pergjithshme patentave dhe markave shtator, 2011

${ }^{13} \mathrm{http}: / /$ www.alpto.gov.al/pdf/raporti_anglisht.pdf
} 
- For the skeptics the consequences of reporting of IP in SMEs financial statements would be a) increase of tax payment, b) complications of book keeping for these entities.

3- Asked about the methods they use for the IP valuation, most of them just register the IP according to the cost model, with the purchasing price and are not involved in the processes of revaluations because it is almost impossible to speak for an active market of intangibles in Albania, according to the directives of IAS 38 or NAS 5.

4- Asked for the possibilities that the Albanian accountant have to properly manage and report an IP effectively, most of the interviewed individuals think that they need more information and training about the IP issues, as the topic is relatively new topic in Albania and, furthermore , they do not have support from the tax officers and other state employers in this issues and a more appropriate staff training is needed to a larger target group, including the third parties.

\section{Main Findings and Conclusions}

The inclusion of IP in financial and accounting statements of entities is an emerging challenge for the accountants and managers of the new, knowledge based economy. There are yet, issues that need to have more attention and to be clear, such as the non recognition of the internally developed IP, the issues of revaluation that is still very sensitive due to the problems that it can produce by implying sharp fluctuations in the balance sheet and earnings rations indicators. These are some of the difficulties that financial and accounting experts are not able to achieve consensus for the proper registration and valuation of IP in the entities financial statements.

Yet despite the difficulties of IP reporting, in the new knowledge based economy, the proper reporting of the IP is a must that have to be achieved.

In this aspect even the developing countries like Albania ,that have adopted the IFRS, are in progress to proper manage the IP issues by facing the gaps that IFRS leave in this aspect and also to meet the challenges that the specific Albanian economy represent.

We find in this study and with the results of the survey that, although the challenges that developed countries have in IP reporting , Albania has it's specific challenges in IP reporting such as:

- Challenges of IP management from the SMEs due to several factors explained above, such as, lack of knowledge, qualified personal, finding of the system complex and expensive etc.

- The impact that the informal economy has in the IP reporting

- The impact that a total missing active market for the intangibles have on the IP reporting.

- The lack of qualifications of accountant and managers in application of IP related accounting standards

- The lack of the knowledge of IP issues by third parties such as tax officers, government institutions and lack of sensibility from the people for the IP related issues.

To conclude, based in our study and the results of the survey, our recommendations in improving the IP reporting in Albania would be :

1- The undertaking of the institutional measures aiming to strengthening financial government institutions, especially customs management and tax administration to fight more efficiently the informal economy. The reduce of the informality will encourage SMEs but not only them to report, and not hide the transactions and the reporting of the IP. This can lead in the beginning of the development of an active market for the intangibles.

2- More efforts need to be undertaken by Albanian IP Directories to make the business owners aware of the benefits that they can profit by properly managing their IP assets and to increase the sensibility of the people in the IP rights.

3- The Albanian Certified Accountants Council in collaboration with Ministry of Finance, should training the certified accountants and audits as well as the tax and administration officers in IP accounting standards and management issues.

\section{References}

Buletini informativ i aktivitetit te zyres Shqiptare per te drejtat e autorit , maj 2011

Buletini i pronesise Intelektuale, Drejtoria e pergjithshme patentave dhe markave shtator, 2011

Example given by the FASB (Financial Accounting Standards Board) at the United Nations Department of Economic and Social Affairs Conference, July 12-13 2006 
Gordon V.SMITH , Russel L.PARR (2011) , Intellectual Property , Valuations , Exploitation and infringement damages pg 50-54 http://www.wipo.int/sme/en/

http://www.alpto.gov.al/pdf/raporti_anglisht.pdf

Licensing Executive Society: Transcription notes of the F-16 Committee Meeting: Reporting Intellectual Property, Washington, D.C., May 2, 2002,

Moerman , L\&Van Der Loan , S (2006) TRIPS and the pharmaceutical industry prescription for profit . Critical perspectives on accounting. 17,1089-11069

Roya Ghafele Associate Economic Officer, Intellectual Property and Economic Development Department, WIPO. .Getting a Grip on Accounting and Intellectual Property.

SEC (Securities and Exchange Commission): Strengthening Financial Markets: Do Investors Have The Information They Need? A Report by the SEC Special Task Force.2001 http://www.mba.yale.edu/news_events/sec_exec_sum.htm

Sharyn Ch'ang and Marina Yastreboff, Intellectual Property Auditing: A Road to Riches , 2001

Stewart, T. (2001). The Wealth of Knowledge: Intellectual Capital and the 21st Century. Organization Currency: New York

Sullivan P. (Jr.) \& Sullivan P. (Sr.) (2000). Valuing intangibles companies - An intellectual capital approach. Journal of Intellectual Capital Management. 1(4), 328- 340 